\title{
Tolerance and Resistance to Viruses and Their Vectors in Vitis sp.: A Virologist's Perspective of the Literature
}

\author{
Jonathan E. Oliver ${ }^{1,2}$ and Marc Fuchs ${ }^{1 *}$
}

\begin{abstract}
Grapevines can be affected by many viruses and viral diseases. However, despite a long history of cultivation and breeding efforts, little useable resistance to viral diseases has been identified in Vitis species. As a result, management of viral diseases has largely relied upon prevention/exclusion or on the use of economically and/ or environmentally consequential methods to manage vector populations. Resistance to dagger nematode vectors has been identified and successfully transferred to rootstock genotypes that are commercially available, but these resistant materials do not prevent virus translocation into the scion, although a significant delay in infection can allow for suitable production. In this review, we critically evaluate the literature regarding resistance against viruses and vectors in Vitis and Muscadinia species. We examine the challenges of breeding grapevines for virus resistance and the methodologies used to test for resistance. The availability of useful sources of resistance and tolerance toward both viruses and their vectors, or lack thereof, is evaluated and discussed in terms of disease management.
\end{abstract}

Key words: Grapevine fanleaf virus, Tomato ringspot virus, Xiphinema index, Xiphinema americanum

\section{A Host of Problems}

Grapevines have been cultivated for thousands of years and on six continents (Burger et al. 2009). They are a highly valuable fruit crop with a $\$ 162$ billion dollar annual impact on the U.S. economy alone (MFK Research 2007). Among the limiting factors affecting grapevine production are viruses. At least 60 virus species are known to affect grapevines (Martelli and Boudon-Padieu 2006), and when other known infectious agents including viroids (five), phytoplasmas (eight), and insect-transmitted xylematic bacteria (one) are included, these 74 intracellular pathogens represent the highest number ever found in a single crop (Martelli and Boudon-Padieu 2006). Viruses can be serious threats to grape production. Some viruses are transmitted from vine to vine by dagger nematodes or mealybugs and soft-scale insects. Present management strategies rely on preventative approaches based on the use of planting material derived from certified, virus-tested stocks. In vineyards where viruses and vectors are present, cultural practices such as roguing, application of pesticides, and planting vines that possess resistance or tolerance to vectors are used to mitigate the impact of viruses. However, these approaches are often costly, environmentally undesirable, or of limited efficacy, and the use of rootstocks with vector resistance or tolerance may have undesired effects

\footnotetext{
${ }^{1}$ Department of Plant Pathology and Plant-Microbe Biology, Cornell University, New York State Agricultural Experiment Station, Geneva, NY 14456; ${ }^{2}$ Department of Entomology and Plant Pathology, Auburn University, Auburn, AL 36849 (presently).

*Corresponding author (email: mf13@cornell.edu; fax: 315787 2389)

Acknowledgments: The authors thank Peter Cousins, USDA-ARS, Geneva, $\mathrm{NY}$, for his valuable suggestions to improve the manuscript.

Manuscript submitted Apr 2011, revised June 2011, accepted Aug 2011

Copyright $(\underset{2}{ } 2011$ by the American Society for Enology and Viticulture. All rights reserved.

doi: 10.5344/ajev.2011.11036
}

on vine growth and quality. Nonetheless, the use of cultivars and rootstocks that are resistant or tolerant to viruses would be ideal to manage virus diseases (Maule et al. 2007). Despite the many viruses that can be a major constraint on grapevine production and the high value of grapevines and their long history of breeding/selection (Burger et al. 2009), little useable resistance to viruses has been identified (Laimer et al. 2009) even though it is obviously desirable. In this review, we examine the current state of knowledge regarding resistance or tolerance to viruses in Vitis and Muscadinia species.

\section{Grapevine: A Unique Host}

Grapevines (genus Vitis) have a long history of cultivation, especially in Europe and the Middle East where the species of European grapevine (Vitis vinifera) is believed to have originated (Burger et al. 2009). Vitis vinifera is by far the most widely cultivated grape species; however, other $V i$ tis species, including V. riparia, V. rupestris, V. candicans, $V$. x slavinii, $V$. longii, $V$. rufotomentosa, $V$. berlandieri, $V$. arizonica, V. x champinii, and V. labrusca, as well as Muscadinia rotundifolia, are also important for other reasons. These reasons include their usefulness in breeding efforts, for grape production, and as rootstock materials to provide many important growth characteristics, including protection of grafted scion cultivars against pathogens, their vectors, and adverse soil conditions.

Grapevines are unique not only because of their perennial life cycle, long history of cultivation, and extensive transfer between continents, but also because individual cultivars have been grafted and propagated vegetatively for substantial periods, which has concurrently made it possible for viruses to easily be moved and disseminated over wide areas together with their grapevine hosts. Transfer of material began taking place long before the discovery of viral pathogens in 1898 (Harrison and Wilson 1999); thus, the infection status of transferred vines was largely unknown. These unique properties 
may partially explain why grapevine is afflicted with such a wide diversity of viral species. In addition, the long-held preferences for a limited number of grapevine cultivars due to their enological properties have complicated efforts to integrate new genetic traits and resistances into cultivated elite varieties (Burger et al. 2009).

\section{Resistance: What Is in a Name?}

Resistance to grapevine viruses is the most desirable means of control, in particular for vector-transmitted viruses once they have become established in a grapegrowing area. However, the term "resistance" when it comes to viruses can refer to a range of plant reactions to virus infection, including, but not limited to, resistance to multiplication, reduced symptoms, delayed infection, or resistance to the virus vector. Often, the simple term resistance can be used interchangeably by plant breeders, virologists, physiologists, viticulturists, or plant pathologists to refer to any one of these situations, which can cause a great deal of confusion (Buddenhagen 1981). For the purposes of this paper, we will differentiate between resistance and tolerance because both terms describe unique virus-host relationships that can differentially impact disease management and production.

Resistance refers to the plant's ability to limit virus multiplication (Fraile and Garcia-Arenal 2010) by interfering with the disease cycle within the host plant (Lecoq et al. 2004). Completely resistant or immune plants are unable to sustain virus replication (Lecoq et al. 2004), while completely susceptible plants do not impair pathogen infection. Between these extremes, plants more able to impair virus replication may be described as showing more resistance than those plants less able to impair virus replication, which are, in turn, more susceptible. Although more resistant plants are often able to produce greater yields in the presence of the virus than more susceptible plants, that may not necessarily be true in all cases, as plants that are more able to impair replication, and thus show lower levels of virus infection, do not necessarily display fewer symptoms of virus infection (Hull 2002, Lapidot et al. 2006). However, a completely resistant plant would be unable to be infected and, of course, would not be expected to show any viral symptoms. Because relative virus multiplication and yield are not always related, so-called tolerance to virus infection has been described.

Tolerance to virus infection is the ability of plants to reduce the damage caused by virus infection to produce a good crop in the presence of a virus (Fraile and García-Arenal 2010, Lecoq et al. 2004). Different degrees of tolerance can be identified (Peng and Moens 2003). More tolerant plants are able to produce a better crop when infected than less tolerant plants. Completely tolerant plants are capable of producing as good a crop whether the pathogen is present or not, and completely intolerant or susceptible plants are unable to produce a crop when infected (Peng and Moens 2003). Most plants fall somewhere between these extremes.

These definitions of tolerance and resistance can also be used to describe the plant's ability to interfere with vector multiplication or to avoid the harmful effects on yield in the presence of the vector, respectively. In the case of viruses transmitted by vectors, the system can be more complicated, in that a resistance or tolerance to a viral vector can appear to be a resistance to a viral disease if the vector's feeding is diminished or prevented - subsequently failing to allow efficient transmission of the virus to the plant host. Once the virus gets in, if the plant cannot prevent virus replication, the virus would be able to replicate in the host and impact yield thereafter. Although not the result of true virus resistance, such a delay of infection may be significant to growers from an economic perspective (Raski et al. 1983), and so it cannot be discounted in a disease management scheme. The impact of such a delayed infection in terms of disease management should be given careful consideration on a case-by-case basis.

\section{Evaluating Resistance and Tolerance to Viruses}

Resistance and tolerance evaluations are often made using a wide range of techniques and by examining a variety of parameters. Since virus symptoms can be quite variable between environmental conditions (Lider and Goheen 1986), reliance on symptoms alone to determine infection can be challenging and may not be an appropriate measure to assess resistance. A serological approach, such as enzyme-linked immuno-sorbent assay (ELISA), is often used to assess the presence of viral proteins - often the coat protein or other structural proteins. Alternatively, nucleic acid-based assays such as reverse transcription-polymerase chain reaction (RTPCR) for RNA viruses or PCR for DNA viruses can be used to determine the accumulation of viral genomic material. Other methods, such as bioassays, can be used to monitor infection with mechanically transmissible viruses. Bioassays rely on transfer of the virus from one host to another host (an indicator host) on which it is known to cause symptoms (or in which it can readily be detected by other means). For virusvector resistance evaluations, relative multiplication estimates are often made for nematodes by comparing gall numbers or by counting numbers of individuals associated with roots or present in soil samples. For mealybugs and scale insects, similar approaches would likely be used for resistance evaluations, but we are not aware of ongoing research efforts in this area. In contrast, evaluations of tolerance often involve comparisons of yield between infected plants and uninfected plants of the same variety or cultivar. Ideally, these comparisons should be made under the same growing conditions. If not, natural variations in yield due to climatic effects, field location, or natural variations between cultivars or advanced breeding material can have a significant impact on yield in their own right. Vigor (as measured by pruning wood weight), weight and number of fruit clusters, and level of soluble solids can be used to quantify virus impact on plant growth, yield, and fruit chemistry as part of a tolerance evaluation.

Here we critically examine the literature using the standards for tolerance or resistance evaluations to establish if tolerance or resistance exists in given grapevine genotypes. Through the use of peer-reviewed evidence for each individual genotype, we will discuss their relative resistance or tolerance, 
where appropriate, to either the virus vectors or the viruses themselves. In each case, we will discuss the usefulness-in a disease management context-of the respective sources of resistance or tolerance for each of the major virus groups.

\section{Testing for Virus Resistance/Tolerance: A Challenge with Grapevines}

Meaningful screens for resistance/tolerance can be challenging with grapevines, primarily due to the perennial nature of the crop and to the extreme difficulty or relative impossibility of mechanically inoculating grapevine tissue with viruses (Valat et al. 2003). Unlike annual crops where resistance/tolerance screens can be conducted in a relatively short time (a few weeks to a few months), and often with more than one round of screening per year, the length of time necessary to evaluate a perennial crop like grapevine is substantially longer because grapevines do not reach full production capacity for a few years after establishment and vines are expected to resist/tolerate pathogen or pest challenges over much longer periods. Additionally, although many herbaceous hosts can be routinely infected with viruses by mechanical means or by Agrobacterium tumefaciens-mediated delivery of viral cDNA, both of which allow for large- scale routine inoculations in controlled experiments, these means of inoculation are ineffective and/or not possible with grapevine, with the exception of the delivery of Grapevine virus A (GVA) cDNA via Agrobacterium tumefaciens (Haviv et al. 2006, Muruganantham et al. 2009). Because of these limitations, the evaluation of grapevines for resistance or tolerance to viruses relies essentially on virus infection via graft inoculation (Lahogue et al. 1995) or vector-mediated infection (Valat et al. 2003) methods, both of which have their own difficulties. Vector-mediated infection studies, which more accurately mirror natural infection conditions in the vineyard, can be difficult due to low or inconsistent levels of inoculum present within a test vineyard (Gonsalves 1982, Harris 1988, Valat et al. 2003). Conversely, graft inoculation may be an inappropriate method of resistance screening in some cases because the inoculation pressure may be too strong to allow for accurate identifications of virus-resistance mechanisms (Esmenjaud and Bouquet 2009, Gonsalves 1982, Lahogue and Boulard 1996).

It is crucial that screens be realistic enough to mimic actual growing conditions, but precise enough to determine subtle differences between resistant varieties. Since individual grapevines may be expected to remain productive for longer

\begin{tabular}{|c|c|c|c|c|}
\hline Virus & Acronym & Family & Genus & Vector(s) \\
\hline \multicolumn{5}{|l|}{ A. Degeneration/decline disease complex } \\
\hline Grapevine fanleaf virus & GFLV & Secoviridae & Nepovirus & Xiphinema index \\
\hline Tomato ringspot virus & ToRSV & & Nepovirus & $X$. rivesi, $X$. americanum, $X$. californicum \\
\hline Tobacco ringspot virus & TRSV & & Nepovirus & X. americanum \\
\hline Peach rosette mosaic virus & PRMV & & Nepovirus & X. americanum, Longidorus diadecturus \\
\hline Blueberry leaf mottle virus & BLMoV & & Nepovirus & Unknown \\
\hline Grapevine Bulgarian latent virus & GBLV & & Nepovirus & Unknown \\
\hline Tomato blackring virus & TBRV & & Nepovirus & L. elongatus, L. attenuatus \\
\hline Artichoke Italian latent virus & AILV & & Nepovirus & Unknown \\
\hline Grapevine Tunisian ringspot virus & GTRV & & Nepovirus & Unknown \\
\hline Arabis mosaic virus & ArMV & & Nepovirus & $X$. diversicaudatum \\
\hline Raspberry ringspot virus & RpRSV & & Nepovirus & Paralongidorus maximus \\
\hline Grapevine deformation virus & GDefV & & Nepovirus & Unknown \\
\hline Grapevine chrome mosaic virus & GCMV & & Nepovirus & Unknown \\
\hline Grapevine Anatolian ringspot virus & GARSV & & Nepovirus & Unknown \\
\hline Cherry leafroll virus & CLRV & & Nepovirus & Unknown \\
\hline Strawberry latent ringspot virus & SLRSV & & Sadwavirus & $X$. diversicaudatum \\
\hline \multicolumn{5}{|l|}{ B. Leafroll disease complex } \\
\hline Grapevine leafroll-associated virus-1 & GLRaV-1 & Closteroviridae & Ampelovirus & $\begin{array}{l}\text { Heliococcus bohemicus, Phenacoccus aceris, } \\
\text { Pseudococcus maritimus, Pulvinaria vitis, Pu. } \\
\text { innumerabilis, Parthenolecanium corni }\end{array}$ \\
\hline Grapevine leafroll-associated virus-2 & GLRaV-2 & & Closterovirus & Unknown \\
\hline Grapevine leafroll-associated virus-3 & GLRaV-3 & & Ampelovirus & $\begin{array}{l}\text { Planococcus ficus, Pl. citri, Ps. Iongispinus, } \\
\text { Ps. affinis, Ps. calceolariae, Ps. maritimus, } \\
\text { Ps. viburni, Ps. comstocki, Ph. aceris, Pu. } \\
\text { vitis, Pu. innumerabilis, H. bohemicus, Coccus } \\
\text { longulus, Coccis hesperidium, Prasaissetia } \\
\text { nigra, Ceroplastes rusci, Saissetia sp. }\end{array}$ \\
\hline Grapevine leafroll-associated virus-4 & GLRaV-4 & & Ampelovirus & Pl. ficus \\
\hline Grapevine leafroll-associated virus-5 & GLRaV-5 & & Ampelovirus & Ps. longispinus, PI. ficus, C. rusci \\
\hline Grapevine leafroll-associated virus- 6 & GLRaV-6 & & Ampelovirus & Unknown \\
\hline Grapevine leafroll-associated virus-7 & GLRaV-7 & & Unassigned & Unknown \\
\hline Grapevine leafroll-associated virus-9 & GLRaV-9 & & Ampelovirus & Ps. longispinus \\
\hline Grapevine leafroll-associated virus-De & GLRaV-De & & Ampelovirus & Unknown \\
\hline Grapevine leafrol-associated virus-Pr & GLRaV-Pr & & Ampelovirus & Unknown \\
\hline Grapevine leafroll-associated virus-Car & GLRaV-Car & & Ampelovirus & Unknown \\
\hline
\end{tabular}


periods than most fruit and vegetable crops, even delayed infections that take a substantial time to appear may be significant to growers. Therefore, precise measurements of the virus's impact on infected vines may be necessary to allow for growers to make appropriate disease management decisions. Likewise, given the high value of grapes, and especially winegrapes, even a mild reduction in yield or alteration in fruit composition after virus infection may have a significant impact on growers, further highlighting the importance of precise evaluative parameters. Since a fully productive grapevine can require much space, controlled-environment experiments can be challenging and realistic field studies are necessary for yield-related measurements. Conversely, since the varied growing conditions in field settings can influence disease symptom severity and yields, several years of field data may need to be collected before conclusions can be drawn. Also, since grapevines are grown in a wide variety of climates and soil conditions, proof of tolerance (i.e., no effects on yield) can be difficult and should involve testing in diverse climatic, soil, and cultivation conditions. Simply observing a given genotype in one field or growing it in a single soil type may mask potential virus-induced effects on yield.

\section{The Many Viral Diseases of Grapevine}

Grapevines can be infected with at least 60 different viral pathogens (Martelli and Boudon-Padieu 2006), but the important viral diseases predominantly consist of four larger groups of viruses (Table 1). These groupings include (1) the degeneration/decline disease complex, consisting of nepoviruses, many of which are transmitted by dagger nematodes; (2) the leafroll disease complex, consisting of several ampeloviruses and other viruses, many of which are vectored by mealybugs or scale insects; (3) the rugose wood disease complex, consisting of vitiviruses, which are transmitted by mealybugs or scale insects; and (4) the fleck disease complex, consisting of marafiviruses and maculaviruses. Other viruses cause less extensive problems on grapevine. Subsequent sections focus on each of these viral disease groups and the current knowledge regarding natural resistance/tolerance to the respective viruses or their vectors.

\begin{tabular}{|c|c|c|c|c|}
\hline Virus & Acronvm & Familv & Genus & Vector(s) \\
\hline \multicolumn{5}{|l|}{ C. Rugose wood disease complex } \\
\hline $\begin{array}{l}\text { Grapevine rupestris stem } \\
\text { pitting-associated virus }\end{array}$ & GRSPaV & Betaflexiviridae & Foveavirus & Unknown \\
\hline Grapevine virus $A$ & GVA & & Vitivirus & $\begin{array}{l}\text { Pl. citri, Pl. ficus, Ps. longispinus, } P \text { s. affinis, } \\
\text { H. bohemicus, Ph. aceris, N. innumerabilis }\end{array}$ \\
\hline Grapevine virus $B$ & GVB & & Vitivirus & PI. ficus, Ps. longispinus, Ps. affinis \\
\hline Grapevine virus $D$ & GVD & & Vitivirus & Unknown \\
\hline Grapevine virus $E$ & GVE & & Vitivirus & Ps. comstocki \\
\hline \multicolumn{5}{|l|}{ D. Fleck disease complex } \\
\hline Grapevine redglobe virus & GRGV & Tymoviridae & Maculavirus & Unknown \\
\hline Grapevine fleck virus & GFkV & & Maculavirus & Unknown \\
\hline Grapevine rupestris vein feathering virus & GRVFV & & Marafivirus & Unknown \\
\hline Grapevine asteroid mosaic-associated virus & GAMaV & & Marafivirus & Unknown \\
\hline Grapevine Syrah virus 1 & GSyV-1 & & Marafivirus & Unknown \\
\hline \multicolumn{5}{|l|}{ E. Other viruses } \\
\hline Potato virus $X$ & $P V X$ & Alfaflexiviridae & Potexvirus & Unknown \\
\hline Grapevine berry inner necrosis virus & GBINV & Betaflexiviridae & Trichovirus & Mites \\
\hline Alfalfa mosaic virus & AMV & Bromoviridae & Alfamovirus & Aphids \\
\hline Cucumber mosaic virus & CMV & & Cucumovirus & Unknown \\
\hline Grapevine angular mosaic virus & GAMoV & & Ilarvirus & Unknown \\
\hline Grapevine line pattern virus & GLPV & & Ilarvirus & Unknown-seed borne \\
\hline Tomato spotted wilt virus & TSWV & Bunyaviridae & Bunyavirus & Unknown \\
\hline Grapevine vein clearing virus ${ }^{a}$ & GVCV & Caulimoviridae & Badnavirus & Unknown \\
\hline Bean common mosaic virus & BCMV & Potyviridae & Potyvirus & Unknown \\
\hline Broadbean wilt virus & BBWV & Secoviridae & Fabavirus & Unknown \\
\hline Carnation mottle virus & CarMV & Tombusviridae & Carmovirus & Unknown \\
\hline Grapevine Algerian latent virus & GALV & & Tombusvirus & Unknown \\
\hline Petunia asteroid mosaic virus & PAMV & & Tombusvirus & Unknown \\
\hline Tobacco necrosis virus $D$ & TNV-D & & Necrovirus & Unknown \\
\hline Tobacco mosaic virus & TMV & Virgaviridae & Tobamovirus & Unknown \\
\hline Tomato mosaic virus & ToMV & & Tobamovirus & Unknown \\
\hline Sowbane mosaic virus & SoMV & Unassigned & Sobemovirus & Unknown \\
\hline Raspberry bushy dwarf virus & RBDV & Unassigned & Idaeovirus & Unknown \\
\hline Grapevine stunt virus & GSV & Unassigned & Unassigned & Unknown \\
\hline Grapevine labile-rodshaped virus & GLRSV & Unassigned & Unassigned & Unknown \\
\hline Putative new virus species ${ }^{b}$ & & Reoviridae & Oryzavirus & Unknown \\
\hline Putative new virus species ${ }^{b}$ & & Luteoviridae & Enamovirus & Unknown \\
\hline Putative new virus species ${ }^{b}$ & & Endornaviridae & Endornavirus & Unknown \\
\hline
\end{tabular}

aZhang et al. (2011).

bSabanadzovic (2009); acronym not applicable. 
Degeneration/decline complex. One of the most important viral diseases of grapevine is fanleaf degeneration/ decline, which is caused by a number of viruses that belong to the genera Nepovirus and Sadwavirus in the family Secoviridae (Martelli and Boudon-Padieu 2006). Many of these viruses are specifically transmitted in a soilborne manner by ectoparasitic nematodes. The first virus confirmed to be transmitted by dagger nematodes was Grapevine fanleaf virus (GFLV) (Hewitt et al. 1958), which remains the most important viral cause of fanleaf degeneration. GFLV can result in severe crop losses of up to $80 \%$ and produce a range of symptoms, including vein banding, yellow mosaic, and epinastic distortion of leaves into a fan-shaped leaf with narrowed interveinal sinuses. GFLV is naturally transmitted in a specific manner by the Longidorid nematode species Xiphinema index and is largely confined to grapevine (Andret-Link et al. 2004). Xiphinema index, like many of the other nematode vectors of degeneration-causing viruses, can be an important pest of grapevine in its own right if populations are high. Since GFLV and its nematode vector have a relatively narrow host range, and since they were the first virus-vector combination identified in grapevine, much work has been done to develop methods to control GFLV (Andret-Link et al. 2004, Boubals and Pistre 1978, Bouquet et al. 2000, 2003a, 2003b, Bouquet and Danglot 1983, Bouquet 1981, 1983a, 1983b, Ipach et al. 2000, Jimenez Diaz and Goheen 1991, Lahogue and Boulard 1996, Lider and Goheen 1986, Raski et al. 1983, Smith et al. 2005, Staudt and Kassemeyer 1990, Walker and Jin 1998, 2000, Walker and Meredith 1990, Walker et al. 1985, 1989, 1991, Walker and Wolpert 1994).

Resistance in grapevines toward other nepoviruses, by contrast, has been less extensively studied. Some of these other nepoviruses include Arabis mosaic virus (ArMV), closely related to GFLV, which can also cause fanleaf degeneration, has a much wider host range than GFLV, and is transmitted by another nematode species, Xiphinema diversicaudatum; Tobacco ringspot virus (TRSV), Peach rosette mosaic virus (PRMV), and Tomato ringspot virus (ToRSV), vectored by Xiphinema americanum; and several other nematode-vectored nepoviruses and a sadwavirus (Table 1A). Since most nepoviruses are transmitted within a vineyard only by nematode vectors, much effort toward controlling these pathogens has focused either on eliminating the nematode vector (AndretLink et al. 2004, Raski et al. 1983) or on controlling virus transmission during vector feeding using resistant grapevine materials, especially rootstock genotypes that may be able to protect an otherwise susceptible scion. Investigations of resistance to GFLV or GFLV transmission are many (Becker 1989, Becker and Sopp 1990, Boubals and Pistre 1978, Bouquet et al. 2000, 2003a, 2003b, Bouquet and Danglot 1983, Bouquet 1981, 1983a, 1983b, Ipach et al. 2000, Jimenez Diaz and Goheen 1991, Lahogue and Boulard 1996, Lider and Goheen 1986, Raski et al. 1983, Smith et al. 2005, Staudt and Kassemeyer 1990, Walker and Jin 1998, 2000, Walker and Meredith 1990, Walker et al. 1985, 1989, 1991, Walker and Wolpert 1994), with several reports of genotypes that are tolerant or less susceptible to the virus than others, or resistant to GFLV transmission. However, none of these studies have found resistance to GFLV that either prevents virus replication or movement into a susceptible grafted scion under field conditions. As of the beginning of 2011, approximately 24 publications have described studies of GFLV-resistant cultivars, often with conflicting findings. By contrast, substantially fewer studies have focused on other nepoviruses, such as ToRSV, PRMV, and ArMV (Allen et al. 1982, Gonsalves 1982, Lahogue and Boulard 1996, Ramsdell et al. 1995), often with similarly conflicting results. A few studies have also focused on the nematode vector $X$. americanum (McKenry et al. 2001, 2004, McKenry and Anwar 2006, Ramsdell et al. 1996).

Theoretically, protection against nepoviruses could be categorized into at least four types: (1) tolerance to the virus's nematode vector; (2) resistance to the virus's nematode vector; (3) tolerance to the virus itself; and (4) resistance to the virus itself. Accordingly, resistance and/or tolerance to either nematodes or viruses has been described. Therefore, we will examine each of these types of resistance or tolerance and discuss the relevance or importance of cultivars or rootstocks displaying each type with respect to virus control, with a particular emphasis on field studies.

Tolerance to nematode vectors. Tolerance to a nematode vector occurs when the cultivar or rootstock, in the presence of the nematode (and in the absence of any virus they transmit), either allows for the same level of production (grape yield/quality) as when the nematode vector is absent (completely tolerant) or yields more production than other cultivars or rootstocks allow in the presence of the nematode (relatively more tolerant). Therefore, studies that examine some component of yield are necessary to prove whether a rootstock or cultivar is tolerant (Peng and Moens 2003, Trudgill 1991). Based on this criterion, several rootstocks or cultivars have been suggested to be tolerant to $X$. index, the nematode vector of GFLV, and X. americanum, the nematode vector of PRMV, ToRSV, and TRSV, or to exhibit relatively more tolerance in comparison with others in field studies (Table 2). In the case of vector tolerance, nematode feeding (probing) on rootstocks is still occurring; hence, these tolerant rootstocks (assuming viral replication is still possible) do not aid in the control of viruses, although these may be important to growers in areas where the nematode is present as the primary constraint on production in the absence of the virus.

Resistance to nematode vectors. If a nematode vector species is completely unable to reproduce on the host grapevine, then that grapevine may be called resistant to that nematode species. If the nematode vector is unable to reproduce as successfully on one cultivar or rootstock versus another in similar growing conditions, then that rootstock or cultivar may be called relatively more resistant (Trudgill 1991). Necessarily, studies purporting this type of resistance must demonstrate lowered nematode reproduction rates or reduced nematode survival when associated with the supposedly resistant rootstocks (Peng and Moens 2003, Trudgill 1991). There has been some success in finding this type of resistance toward some nepovirus vectors in grapevine cultivars (Table 3). With respect to $X$. index, the nematode vector of GFLV, Muscadinia 
rotundifolia and hybrid crosses between $M$. rotundifolia and Vitis species reportedly show high resistance to $X$. index (Aballay et al. 1998, Bouquet et al. 2003a, 2003b, Esmenjaud et al. 2010, Staudt and Weischer 1992, Walker and Jin 1998, Walker et al. 1991) with few or no root-associated nematodes found and reactions to nematode feeding on roots that appear to be a hypersensitive response (Staudt and Weischer 1992). Similarly, the rootstock Börner (Hafner 1998), which results from a cross of $V$. riparia 183 Geisenheim and $V$. cinerea Arnold, has been reported to resist galling by $X$. index (Becker 1989, Becker and Sopp 1990, Sopp et al. 1998). Other rootstocks that are resistant to this nematode species include Vitis arizonica (Van Zyl et al. 2009, Weischer 1980, Wheeler and Walker 2005), and recent work with this species has led to the identification of the first major genetic locus responsible for resistance to an ectoparasitic nematode in grapevine (XiRl;
Xiphinema index resistance locus 1) (Hwang et al. 2010, Xu et al. 2008). This new genetic information will facilitate the use of marker-assisted selection in the breeding of new grapevine rootstocks with resistance to $X$. index (Xu et al. 2008). Many other genotypes and hybrids have resistance to $X$. index and $X$. americanum (Table 3 ), but only a fraction have been released to growers.

None of the rootstocks that are highly resistant to $X$. index have been found to prevent replication of GFLV (Boubals and Pistre 1978, Bouquet 1983a, 1983b, Bouquet et al. 2003a, 2003b, Bouquet and Danglot 1983, Ipach et al. 2000, Laimer et al. 2009, Malan and Meyer 1993, Walker et al. 1985), nor do they prevent the translocation of GFLV to susceptible scions, although some substantially delay the movement of GFLV and reduce the infection rate of test vines in field settings, possibly through a reduction in nematode populations and

\begin{tabular}{|c|c|c|}
\hline Virus vector/Species or cross & Materials & Tolerance indicated (tolerance not confirmed) \\
\hline \multicolumn{3}{|l|}{ X. americanum } \\
\hline$V$. vinifera Mourvedre $\times$ V. rupestris $\times$ V. rupestris Martin & $1202 C$ & aRamsdell et al. 1996 \\
\hline$V$. solonis $\times$ V. riparia & $1616 C$ & aRamsdell et al. 1996 \\
\hline$V$. riparia $\times$ V. rupestris & $3309 C$ & aRamsdell et al. 1996 \\
\hline \multirow[t]{2}{*}{ V. berlandieri x V. riparia } & Teleki 5A & aRamsdell et al. 1996 \\
\hline & Kober 5BB & aRamsdell et al. 1996 \\
\hline 101-14 x Goldriesling & Foch & aRamsdell et al. 1996 \\
\hline Seibel 5656 x Seibel 4986 & Seyval & aRamsdell et al. 1996 \\
\hline Seibel 6905 x Pinot de Corton & Vignoles & aRamsdell et al. 1996 \\
\hline Seibel 4986 x Ugni blanc & Vidal & aRamsdell et al. 1996 \\
\hline \multicolumn{3}{|l|}{$X$. index } \\
\hline \multirow[t]{3}{*}{ V. vinifera $\times$ M. rotundifolia } & O39-16 & aLider and Goheen 1986, aWalker et al. 1989, a1994 \\
\hline & $043-43$ & aLider and Goheen 1986, aWalker et al. 1989, a1994 \\
\hline & $\mathrm{O} 44-44$ & aLider and Goheen 1986 \\
\hline \multirow[t]{3}{*}{ V. rufotomentosa $\times$ V. vinifera } & $171-6$ & aLider and Goheen 1986 \\
\hline & $171-13$ & aHarris 1988 \\
\hline & $171-52$ & aHarris 1988 \\
\hline \multirow[t]{3}{*}{ V. x champinii } & & (bMeredith et al. 1982) \\
\hline & Dog Ridge & aHarris 1988 \\
\hline & Salt Creek & aHarris 1988 (bMeredith et al. 1982) \\
\hline 1613C $\times$ V. rupestris Metallique & $122-16$ & aHarris 1988 \\
\hline$V$. riparia $\times$ V. rupestris & $101-14$ & aHarris 1988 \\
\hline$V$. berlandieri $\times$ V. riparia & $\mathrm{SO} 4$ & aHarris 1988 \\
\hline V. slavinii $x$ V. rupestris Metallique & $88-113$ & aHarris 1988 \\
\hline V. rufotomentosa $\times$ V. candicans & $142-40$ & aHarris 1988 \\
\hline$V$. berlandieri $\mathrm{x} V$. rupestris & $110 \mathrm{R}$ & aHarris 1988 \\
\hline V. arizonica $\times$ V. candicans & $101-56$ & aHarris 1988 \\
\hline V. longii $x(V$. riparia Gloire $x$ V. x champinii Ramsey) & $106-38$ & aHarris 1988 \\
\hline \multirow[t]{2}{*}{ V. candicans $\times 1613 \mathrm{C}$} & $116-11$ & aHarris 1988 \\
\hline & $116-60$ & aHarris 1988 \\
\hline V. rufotomentosa x ( V. riparia Gloire x Dog Ridge) & $514-11$ & aHarris 1988 \\
\hline (V. riparia Gloire x Dog Ridge) x 1613C & $112-2$ & aHarris 1988 \\
\hline V. arizonica & & bMeredith et al. 1982 \\
\hline V. rufotomentosa & & bMeredith et al. 1982 \\
\hline V. candicans & & bMeredith et al. 1982 \\
\hline V. slavinii & & bMeredith et al. 1982 \\
\hline V. solonis & & bMeredith et al. 1982 \\
\hline V. riparia Gloire & & bMeredith et al. 1982 \\
\hline
\end{tabular}

aBased on yield or vigor determination.

bBased on other measure of host performance (root damage) 
Table 3 Grapevine materials with resistance to nematode vectors of viruses.

\begin{tabular}{lll}
\hline Virus vector/Species or cross & Materials & $\begin{array}{l}\text { Resistance indicated } \\
\text { (resistance not confirmed) }\end{array}$ \\
\hline $\begin{array}{l}X . \text { americanum } \\
\text { V. vinifera } \text { M M. rotundifolia }\end{array}$ & O39-16 & $\begin{array}{l}\text { McKenry et al. 2001, 2004 } \\
\text { (McKenry and Anwar 2006) }\end{array}$ \\
\hline
\end{tabular}

\section{$X$. index}

$V$. vinifera $\times M$. rotundifolia

Mtp 3146-1-87

039-16

O43-43

VRH 8771

VRH 97-99-79

NC $35-50$

VMH 11-6-76

\begin{tabular}{ll}
\hline V. riparia $\times$ V. cinerea & Börner \\
\hline V. riparia $\times$ V. rupestris & Schwarzmann \\
& $3309 \mathrm{C}$
\end{tabular}

\section{V. arizonica}

\begin{tabular}{ll} 
& $\begin{array}{l}\mathrm{b} 40-14 \\
\mathrm{~b} 42-26\end{array}$ \\
\hline V. candicans & Solonis \\
\hline V. longii & Solonis \\
\hline V. x champinii & Dog Ridge
\end{tabular}

Salt Creek

V. rupestris $\times$ M. rotundifolia

\begin{tabular}{|c|c|c|}
\hline & $\begin{array}{l}8913-02 \\
8913-21\end{array}$ & $\begin{array}{l}\text { Walker and Jin } 1998 \\
\text { Walker and Jin } 1998\end{array}$ \\
\hline V. berlandieri $\times$ V. rufotomentosa & & Walker and Jin 1998, 2000 \\
\hline \multirow[t]{4}{*}{ M. rotundifolia } & & $\begin{array}{l}\text { Boubals and Pistre 1978, Sopp et al. } 1998, \\
\text { Staudt and Weischer } 1992\end{array}$ \\
\hline & Noble & Bouquet et al. 2000 \\
\hline & Carlos & Bouquet et al. 2000 \\
\hline & Yuga & Bouquet et al. 2000 \\
\hline V. munsoniana & & Staudt and Weischer 1992 \\
\hline V. riparia $\mathrm{x}$ V. berlandieri & $161-49 \mathrm{C}$ & $\begin{array}{l}\text { Boubals and Pistre 1978, aCoiro et al. } 1985, \\
\text { aMalan and Meyer } 1993\end{array}$ \\
\hline \multirow[t]{3}{*}{ V. berlandieri $\mathrm{x}$ V. riparia } & Teleki 5A & Coiro et al. $1985,{ }^{c} 1990$ \\
\hline & Teleki 5C & $\begin{array}{l}\text { Coiro et al. } 1985 \\
\text { (Boubals and Pistre 1978, Coiro et al. 1990, McKenry et al. 2004, } \\
\text { McKenry and Anwar 2006, Sopp et al. 1988) }\end{array}$ \\
\hline & $\mathrm{SO} 4$ & $\begin{array}{l}\text { Boubals and Pistre 1978, Coiro et al. } 1985 \\
\text { (Coiro et al. 1990, Harris 1983, Malan and Meyer 1993, } \\
\text { McKenry and Anwar 2006) }\end{array}$ \\
\hline \multirow[t]{3}{*}{ V. riparia } & & $\begin{array}{l}\text { Boubals and Pistre 1978, aKunde et al. } 1968 \\
\text { (Walker and Jin 1998, 2000) }\end{array}$ \\
\hline & De Pailleìres & Coiro et al. 1985 \\
\hline & Gloire de Montpellier & $\begin{array}{l}\text { Boubals and Pistre 1978, aCoiro et al. 1985, aKunde et al. } 1968 \text {, } \\
\text { aStaudt and Kassemeyer } 1990 \\
\text { (Esmenjaud et al. 2010, Malan and Meyer 1993) }\end{array}$ \\
\hline
\end{tabular}

Bouquet et al. 2000

Bouquet et al. 2000, 2003a, 2003b

Aballay et al. 1998, McKenry and Anwar 2006, McKenry et al. 2001, 2004, Staudt and Kassemeyer 1990, Walker and Jin 1998 , Walker et al. 1989, 1991

aStaudt and Kassemeyer 1990, Walker et al. 1989

Esmenjaud et al. 2010

Esmenjaud et al. 2010

Esmenjaud et al. 2010

Bouquet et al. 2003a

Becker and Sopp 1990, Becker 1989, Ipach et al. 2000, Sopp et al. 1998

aCoiro et al. 1985, Harris 1983, aMcKenry et al. 2001, McKenry and Anwar 2006

Boubals and Pistre 1978, Harris 1983

(Bouquet et al. 2000, McKenry et al. 2001, 2004)

Harris 1983, Kunde et al. 1968, Staudt and Kassemeyer 1990, Weischer 1980, Wheeler and Walker 2005

Van Zyl et al. 2009

Hwang et al. 2010, Xu et al. 2008

Harris 1983, Kunde et al. 1968, Weischer 1980

Coiro et al. 1985

(Kunde et al. 1968)

(Kunde et al. 1968)

Boubals and Pistre 1978, bCoiro et al. 1990

(Aballay et al. 1998, Kunde et al. 1968, Malan and Meyer 1993,

McKenry et al. 2001, McKenry and Anwar 2006)

bCoiro et al. 1990

(Boubals and Pistre 1978, Kunde et al. 1968,

McKenry et al. 2001, 2004, McKenry and Anwar 2006)

Walker and Jin 1998, 2000

Walker and Jin 1998

Walker and Jin 1998

Bubals and Pistre 1978, Sopp et al. 1998

Bouquet et al. 2000

Bouquet et al. 2000

Malan and Meyer 1993

Coiro et al. 1985

(Boubals and Pistre 1978, Coiro et al. 1990, McKenry et al. 2004,

(Coiro et al. 1985 McKenry and Anwar 2006)

Boubals and Pistre 1978, aKunde et al. 1968

Walker and Jin 1998, 2000)

(Esmenjaud et al. 2010, Malan and Meyer 1993)
Boubals and Pistre 1978, aCoir
aStaudt and Kassemeyer 1990 
Table 3 (cont.) Grapevine materials with resistance to nematode vectors of viruses.

\begin{tabular}{|c|c|c|}
\hline Virus vector/Species or cross & Materials & $\begin{array}{l}\text { Resistance indicated } \\
\text { (resistance not confirmed) }\end{array}$ \\
\hline \multirow[t]{2}{*}{ V. riparia (continued) } & Fabre & Coiro et al. 1985 \\
\hline & Gran Glabre & ${ }^{a}$ Coiro et al. 1985 \\
\hline \multirow[t]{3}{*}{ V. berlandieri $x$ V. rupestris } & 57 Richter & ${ }^{a}$ Coiro et al. 1985 \\
\hline & 110 Richter & $\begin{array}{l}\text { Boubals and Pistre 1978, aCoiro et al. } 1985 \\
\text { (Harris 1983) }\end{array}$ \\
\hline & 770 Paulsen & ${ }^{a}$ Coiro et al. 1985 \\
\hline $\begin{array}{l}\text { V. riparia } \times \text { V. vinifera Carignon } \\
(\text { Castel } 15-612) \times \text { V. rupestris du Lot }\end{array}$ & Golia & Coiro et al. 1985 \\
\hline \multirow{2}{*}{$\begin{array}{l}\text { V. berlandieri x (Aramon }-V \text {. rupestris } \\
\text { Ganzin 1) }\end{array}$} & 2413 Grimaldi & aCoiro et al. 1985 \\
\hline & 1045 Paulsen & $\begin{array}{l}\text { Coiro et al. } 1985 \\
\text { (Malan and Meyer 1993) }\end{array}$ \\
\hline V. vinifera Trollinger $\times$ V. riparia & $26 \mathrm{G}$ & Coiro et al. 1985 \\
\hline V. solonis & & Harris 1983, Kunde et al. 1968 \\
\hline V. smalliana & & Harris 1983, Kunde et al. 1968 \\
\hline V. slavinii x V. riparia Gloire & $86-10$ & Harris 1983 \\
\hline V. riparia Gloire $x$ V. candicans & $91-39$ & Harris 1983 \\
\hline \multirow[t]{2}{*}{$V$. arizonica $\times$ V. candicans } & $101-56$ & Harris 1983 \\
\hline & $101-9$ & Harris 1983 \\
\hline $\begin{array}{l}\text { V. longii } x[\text { V. riparia Gloire } \mathrm{x} \\
\text { V. x champinii Ramsey] }\end{array}$ & $106-38$ & Harris 1983 \\
\hline \multirow[t]{2}{*}{ [V. riparia Gloire x Dog Ridge] x $1613 \mathrm{C}$} & $112-2$ & Harris 1983 \\
\hline & $112-71$ & Harris 1983 \\
\hline \multirow[t]{2}{*}{ V. candicans $\times 1613 \mathrm{C}$} & $116-11$ & Harris 1983 \\
\hline & $116-60$ & Harris 1983 \\
\hline V. rufotomentosa & & Harris 1983, Kunde et al. 1968 \\
\hline V. rufotomentosa $\times$ V. longii & $150-5$ & Harris 1983 \\
\hline \multirow{3}{*}{$V$. rufotomentosa $\times V$. vinifera } & $171-13$ & Harris 1983 \\
\hline & $171-6$ & McKenry et al. 2001 \\
\hline & $171-52$ & Harris 1983 \\
\hline V. rufotomentosa $\times$ V. rupestris Metallique & $176-9$ & Harris 1983 \\
\hline V. rufotomentosa x. V. riparia Gloire & $513-4$ & Harris 1983 \\
\hline $\begin{array}{l}\text { V. rufotomentosa x [V. riparia Gloire } \mathrm{x} \\
\text { Dog Ridge] }\end{array}$ & $514-11$ & Harris 1983 \\
\hline $\begin{array}{l}\text { V. rufotomentosa } \times \text { [V. riparia Gloire } \mathrm{x} \\
\text { V. } x \text { champinii] }\end{array}$ & $515-1$ & Harris 1983 \\
\hline \multirow[t]{2}{*}{$V$. rufotomentosa $\times$ V. candicans } & $142-40$ & Harris 1983 \\
\hline & $142-50$ & Harris 1983 \\
\hline V. solonis $\times$ V. candicans & $187-24$ & Harris 1983 \\
\hline V. solonis $\mathrm{x}$ Othello & $1613 \mathrm{C}$ & $\begin{array}{l}\text { Coiro et al. 1990, aHarris 1983, aKunde et al. } 1968 \text {, } \\
\text { Malan and Meyer } 1993 \\
\text { (Aballay et al. } 1998 \text {, McKenry et al. 2001, McKenry and } \\
\text { Anwar 2006, Boubals and Pistre 1978) }\end{array}$ \\
\hline V. slavinii & & aKunde et al. 1968 \\
\hline \multirow[t]{2}{*}{ V. cinerea } & & (Kunde et al. 1968) \\
\hline & Arnold & Sopp et al. 1998 \\
\hline \multirow[t]{2}{*}{ 1613C x Dog Ridge } & Freedom & $\begin{array}{l}\text { Harris 1983, Malan and Meyer 1993, McKenry and Anwar 2006, } \\
\text { McKenry et al. 2001, } 2004\end{array}$ \\
\hline & Harmony & $\begin{array}{l}\text { Aballay et al. } 1998,{ }^{\circ} \text { Coiro et al. 1990, Harris } 1983 \text {, Malan and } \\
\text { Meyer 1993, McKenry and Anwar 2006, McKenry et al. } 2004 \\
\text { (Lider and Goheen 1986, McKenry et al. 2001) }\end{array}$ \\
\hline V. rubra palmata & & aKunde et al. 1968 \\
\hline VRH8771 x 140 Ruggeri & RPG1 & Esmenjaud et al. 2010 \\
\hline $\begin{array}{l}\text { V. vinifera Mourvedre } \mathrm{x} V \text {. rupestris } \mathrm{x} \\
\text { V. rupestris Martin }\end{array}$ & $1202 C$ & Boubals and Pistre 1978 \\
\hline
\end{tabular}

a Moderate resistance.

${ }^{\mathrm{b}}$ Resistance to California $X$. index populations only, not other $X$. index populations tested.

${ }^{c}$ Resistance to Italian, Israeli, and French $X$. index populations only, not to a Californian $X$. index population. 
therefore subsequent feeding events. This has led a series of rootstocks such as Dog Ridge (Harris 1988), Ramsey (Harris 1988), Börner (Becker 1989), Schwarzmann (McKenry et al. 2001), and O39-16 (Walker et al. 1989, 1991) to be recommended over time for fanleaf-affected sites. In a 12-year field trial in $X$. index and GFLV-infected fields in California, Cabernet Sauvignon grafted onto O39-16 remained uninfected with GFLV for nine years before virus infection of the scion could be detected in the tenth year of the study (Walker et al. 1994, Walker and Wolpert 1994). Börner has also been reported to resist $X$. index-mediated transmission of GFLV (Becker 1989, Becker and Sopp 1990, Sopp et al. 1998), but longer-term studies have shown that Börner vines eventually do become infected (Esmenjaud and Bouquet 2009, Ipach et al. 2000). While in some cases a delay in infection may provide economic benefits to growers dealing with $X$. index and GFLV, ultimately, if the vines are infected, then such a delay is not adequate for control of GFLV in a vineyard setting. In addition, some of these rootstocks have undesired viticultural characteristics. For example, O39-16 is highly vigorous (Walker and Jin 1998) and has poor rooting ability (Bouquet et al. 2003a, 2003b), while Börner and other promising species and muscadine hybrids have been shown to be highly susceptible to lime-induced chlorosis (Bouquet 1991, Esmenjaud and Bouquet 2009).

It has been suggested that some other recently released rootstocks, RS-3 (Ramsey x Schwarzmann), and RS-9 (Ramsey x Schwarzmann), possess broad resistance to nematode species including the dagger nematodes $X$. index and $X$. americanum (Anwar and McKenry 2000, 2002); however, at the time of compiling this review, no peer-reviewed articles have been published describing their level of resistance to dagger nematodes or their competency at preventing nepovirus spread. The same is also true for GRN-1 ( $V$. rupestris $x$ M. rotundifolia), GRN-2 ( $V$. rofotomentosa x [Dog Ridge x Riparia Gloire]) x Riparia Gloire), GRN-3 and GRN-4 (V. rofotomentosa x [Dog Ridge x Riparia Gloire]) x $V$. champinii c9028), and GRN-5 ([Ramsey x Riparia Gloire] x $V$. champinii c9021) (Walker 2009). The purported resistance of those genotypes may have been delivered from the parentage of several rootstocks, which have already been described as a source of nematode resistance or tolerance: Dog Ridge, Gloire de Montpellier, Ramsey, Schwarzmann, or $M$. rotundifolia.

Tolerance to nepoviruses. A cultivar or rootstock that can be infected by a nepovirus but does not suffer negative effects on yield or plant growth would be considered tolerant to the infecting virus. If the cultivar or rootstock does not suffer as much yield loss as other cultivars or rootstocks upon infection, then that cultivar or rootstock may be called relatively more tolerant to the nepovirus. Regarding tolerance to nepoviruses in rootstock or scion varieties, little published information is available. However, one small trial of American and interspecific hybrids did suggest tolerance to PRSV in some cultivars when yield and growth data from infected and uninfected vines were compared (Ramsdell et al. 1995).

In the case of scions grafted to rootstocks, tolerance to the virus infection potentially could be provided by either the rootstock or the scion. In addition to resistance to $X$. index, some studies have reported that susceptible scions grown on O39-16 and related hybrid rootstocks do not show the usual yield losses associated with GFLV infection, even when GFLV infection is detected in these scion materials (Walker and Wolpert 1994, Walker et al. 1994). The yields of scions grafted onto these rootstocks are less affected by GFLV infection than scions grafted onto more conventional rootstocks, which could indicate that these former rootstocks are capable of providing some level of tolerance to GFLV-infection to their grafted scions, perhaps through the production of phytohormones such as cytokinin (Smith et al. 2005). Since these vines still become infected with GFLV, this type of tolerance would not help in controlling the virus, but it would possibly provide economic and production benefits to growers. However, while tolerant materials are potentially desirable, virus symptoms and their effects on yield are notoriously variable (Lider and Goheen 1986) and seem to be affected by even relatively slight changes in climatic or growing conditions. For this reason, and given that vines infected with GFLV tend to degenerate over time, it is especially important that realistic field trials of potentially tolerant materials be undertaken in a diversity of growing and climatic conditions and over an extended period. Ideally, yields of both infected and uninfected vines grafted onto tolerant rootstocks should be evaluated before the virus tolerance of grafted scions can be concluded, although such a study may be challenging in a field setting because of soilborne nematode transmission. To our knowledge, this type of comparative yield study has not been conducted with the reportedly GFLV-tolerant rootstocks. Therefore, the potential of nepovirus-tolerant rootstocks at providing virus tolerance to grafted scion varieties has not been conclusively shown.

Resistance to nepoviruses. If a nepovirus is completely unable to replicate effectively within a host grapevine, then that grapevine may be called resistant to that nepovirus. Several studies have looked at resistance to nepoviruses (Allen et al. 1982, Becker 1989, Boubals and Pistre 1978, Bouquet 1981, 1983a, 1983b, Bouquet et al. 2000, 2003a, 2003b, Bouquet and Danglot 1983, Dias 1980, Gonsalves 1982, Ipach et al. 2000, Jia and Walker 1995, Jimenez Diaz and Goheen 1991, Lahogue and Boulard 1996, Lider and Goheen 1986, Ramsdell et al. 1995, Smith et al. 2005, Staudt and Kassemeyer 1990, Stellmach and Berres 1986, Uyemoto et al. 1977, Walker and Jin 1998, 2000, Walker and Meredith 1990, Walker and Wolpert 1994, Walker et al. 1985, 1989, 1991). Some resistance has been reported to TRSV and ToRSV in a few interspecific hybrids derived from $V$. labrusca or $V$. rupestris (Allen et al. 1982, Gonsalves 1982, Uyemoto et al. 1977). Additionally, resistance to PRMV in the interspecific hybrid Seyval blanc has been reported (Ramsdell et al. 1995), and resistance to TBRV has also been reported in some cultivars of $V$. vinifera, $V$. labrusca, and interspecific hybrids (Dias 1980); however, for both PRMV and TBRV, data to verify these claims are limited. Resistance toward GFLV has been reported in some Middle Eastern cultivars of $V$. vinifera, other Vitis species, and muscadines (Becker 1989, Jimenez 
Diaz and Goheen 1991, Walker and Meredith 1990, Walker et al. 1985). However, few of these conclusions appear to have been examined in subsequent work, or, in some cases, have not been confirmed by subsequent studies (Esmenjaud and Bouquet 2009, Staudt and Kassemeyer 1990, Walker and Wolpert 1994), stressing the value of multiple-site vineyard trials. Some studies of GFLV resistance involving graft inoculation, micrografting, or nematode inoculations in pots have appeared to reveal differences among cultivars with regard to infectivity in the short term (Becker 1989, Becker and Sopp 1990, Boubals and Pistre 1978, Staudt and Kassemeyer 1990, Staudt 1997, Walker et al. 1985), only to have these cultivars become infected in longer-term studies (Bouquet et al. 2000, Esmenjaud and Bouquet 2009, Walker and Wolpert 1994), indicating that they are not resistant to virus replication. Accordingly, there are currently no rootstocks or cultivars available with resistance to GFLV in Vitis species nor any recognized sources of useful resistance (Laimer et al. 2009). Previously, muscadine grapes (Muscadinia rotundifolia) and Muscadinia-Vitis hybrids, including O39-16 and O43-43, were believed to possess resistance to GFLV (Walker et al. 1985, 1989). However, this resistance appears to be a resistance to $X$. index transmission of GFLV rather than a replication resistance (Bouquet 1981, Staudt and Weischer 1992), since muscadine grapes and hybrids can be infected with GFLV, although at a low rate (Bouquet 1981, Bouquet et al. 2000, Staudt and Weischer 1992, Walker and Wolpert 1994). This lowered rate of infection is presumably due to the apparent hypersensitive reaction of these rootstocks to feeding by X. index (Sopp et al. 1998, Staudt and Weischer 1992). Likewise, only a few rootstocks and cultivars appear to have resistance to ToRSV and TRSV, although some of the findings on rootstocks are conflicting (Allen et al. 1982, Gonsalves 1982, Stobbs et al. 1988, Uyemoto et al. 1977). Even though resistance acting on virus replication or preventing virus movement from the rootstock to a scion variety would be economically beneficial to growers and allow for virus control in a field setting, no resistance in any source material has produced a grapevine that is resistant to GFLV or ArMV (Laimer et al. 2009).

Leafroll disease complex. Leafroll disease is an important viral disease of grapevine that occurs in all of the world's grapegrowing areas. Leafroll can cause significant yield losses, delayed fruit ripening, and an overall decline in vine vigor (Martelli and Boudon-Padieu 2006). Leafroll is caused by at least 11 different viral species, the majority of which are transmitted by mealybugs and soft-scale insects (Table 1B).

Of the relatively few published studies that have examined leafroll resistance or tolerance (Ioannou et al. 1997, Kovacs et al. 2001, Lahogue and Boulard 1996), no leafroll-resistant materials have been identified. Asymptomatic infections of cultivated V. labrusca and interspecific hybrids are common (Kovacs et al. 2001), and while latent infections with leafroll viruses may indicate some level of tolerance, neither hybrid vines nor $V$. vinifera cultivars are free from the negative effects of leafroll disease on fruit quality (Kovacs et al. 2001, Wolpert and Vilas 1992). Observed differences in relative vi- rus titers in host plants (Boscia et al. 1991, Credi and Santucci 1991, Ioannou et al. 1997, Kovacs et al. 2001) may suggest some differences in the ability of leafroll viruses to infect some cultivars. Nonetheless, there are currently no commercially available leafroll-resistant cultivars and no recognized sources of useful resistance (Martelli and Boudon-Padieu 2006). We are unaware of any studies of resistance or tolerance to mealybugs and soft scales, although, given the relative diversity of these vector species compared to those transmitting nepoviruses, resistance to one or a few of these vectors may not be effective as a means of control for leafroll viruses.

Rugose wood disease complex. Several viruses are known to cause rugose wood disease on grapevine (Table 1C). Some of these are vectored by mealybugs and scale insects. While these viruses cause less vigorous growth, delayed bud opening, and a general decline in vigor, this disease is named based upon the formation of "corky rugose wood," which occurs in certain cultivars. In these cultivars, a spongy-textured, thick, and corky layer of bark is formed above the graft union, and the stem is often marked by pits and grooves on scions and/or rootstocks (Credi et al. 1991, Martelli and BoudonPadieu 2006). Several rootstocks and cultivars of grapevine have been noted to be especially sensitive to rugose wood (Abracheva 1981, Credi et al. 1991, Téliz et al. 1980a, 1980b, 1981, Téliz and Valle 1980), but there is no commercially available resistance or recognized sources of useful resistance to these viruses or to their vectors (Martelli and BoudonPadieu 2006).

Fleck disease complex. The fleck disease complex consists of at least four viruses (Table 1D) that have no known vectors. Vines affected by this disease may exhibit leaf wrinkling or twisting and stunting, with reduced rooting ability or poor graft-take. Some fruit effects, including higher titratable acidity levels and lower soluble solids, may also be observed in coinfections of fleck virus with other viruses (Kovacs et al. 2001); however, asymptomatic infections with these viruses are quite common (Martelli and Boudon-Padieu 2006), indicating there may be some tolerance to these viruses in Vitis species. There are currently no grapevines recognized to be resistant to these viruses (Martelli and Boudon-Padieu 2006), but further work is necessary before conclusions can be drawn.

Other viral diseases. There are several other viral agents known to infect grapevine (Table 1E), causing a variety of diseases. However, presumably because these viruses seem to be less widespread and are of relatively low economic importance, there has been little work in identifying resistance or tolerance to them (Stobbs and Broadbent 1993).

\section{Observations and Conclusions}

Despite a long history of cultivation, numerous viruses and viral diseases, and extensive efforts to identify useful sources of natural resistance to viruses or their vectors in wild and cultivated Vitis and Muscadinia germplasm, there remains no proven useful resistance to grapevine viruses. Traditional breeding efforts have been successful at identifying sources of resistance to $X$. index and, to a lesser extent, 
to $X$. americanum, but these materials do not prevent virus infection or movement from rootstocks to grafted scion cultivars. They may be very useful against the vector itself in those cases where it may be a significant economic problem in grape production or to mitigate the impact of GFLV on yield by delaying the debilitating effects of virus infection so that these do not take place during early stages of grapevine development. However, these sources of nematode resistance are not sufficient to control GFLV in a vineyard setting, since these materials can still be infected with nepoviruses and $X$. index transmission of GFLV from these materials to other susceptible material can still occur. Recent advances in markerassisted selection (Burger et al. 2009, Hwang et al. 2010, Xu et al. 2008) and grapevine genomic knowledge (Jaillon et al. 2007, Velasco et al. 2007) may prove invaluable in discovering solutions to virus problems; however, to date, no genes or genetic loci have been identified which confer resistance to any virus in grapevine (Fraile and Garcia-Arenal 2010, Martelli and Boudon-Padieu 2006, Maule et al. 2007). Continued efforts to find useful resistance to grapevine viruses must be undertaken and the importance of realistic field trials should not be understated.

Unfortunately, virus resistance evaluations in grapevine are complicated by several factors, not the least of which are the difficulty of testing a perennial crop and the difficulties involved in mechanically inoculating grapes with viruses. Although the first difficulty is unavoidable, resistance screens could be facilitated if a better delivery system were available for viruses (Valat et al. 2003). Research into delivery systems has yielded some promising results using agro-infection to deliver GVA (Muruganantham et al. 2009), but more progress is needed to develop a routine system for grapevine virus infection. Adapting agro-infiltration technology to other grapevine viruses would be desirable. An efficient system for virus delivery, such as agro-infiltration, may allow more effective resistance screens to be set up with quantified inoculum levels, consistent inoculum delivery, and potentially shorter screening times. That would be in stark contrast to the lack of control of virus inoculum load provided by the graft-inoculation methods currently used or to the inconsistent distribution of viruses and their vectors in field testing, which in part accounts for the prolonged exposure necessary to ensure virus delivery in many resistance screens. The overwhelming majority of research efforts have focused on identifying resistance to GFLV and its nematode vector, but resistance to GFLV has not been found. Also, despite their increasingly important impacts on grape production, relatively little is known about other grapevine viruses and vectors, including the mealybugtransmitted leafroll-associated viruses. Thus, there remains an urgent need to develop grapevine material with resistance to GFLV and other viruses.

For grapevine viruses where no source of resistance has been identified despite extensive study, genetic engineering is likely the only approach to achieve resistance. Efforts on engineering resistance to viruses in grapevine through pathogen-derived resistance or RNA-silencing based ap- proaches have provided alternative means for developing resistance to many grapevine viruses, including GFLV, GCMV, GVA, GVB, ArMV, ToRSV, GBINV, and GLRaV-2 in herbaceous hosts (Andret-Link et al. 2004, Burger et al. 2009, Fuchs 2003, Laimer et al. 2009). However, despite promising results (Andret-Link et al. 2004, Burger et al. 2009, Laimer et al. 2009), the translation of laboratory knowledge to real-world solutions has been quite slow (Laimer et al. 2009). Although little work has been done with transgenic resistance technologies under field conditions, a 3-year field trial of transgenic rootstocks indicated a few GFLV-resistant clones (Vigne et al. 2004). However, as has been observed in many of the studies of GFLV-resistant materials examined in this review, three years of field testing are not necessarily adequate to confirm the efficacy of the engineered resistance and longer-term field trials of transgenic materials are needed. It would be desirable to explore this innovative technology more aggressively to engineer virus resistance because its safety and efficacy as a disease management option have been proven in other crops, including summer squash, papaya, and plum (Oliver et al. 2011). Efforts are ongoing in several countries to obtain virus-resistant transgenic grapevines (Laimer et al. 2009). Additionally, efforts to stack resistance to $X$. index and transgenic resistance to GFLV in a single rootstock to manage fanleaf degeneration are underway (Bouquet et al. $2003 a, 2003 b)$. Stacking resistance to both the virus and the vector in a single rootstock would allow for more efficient management of this virus/vector pathosystem and would therefore be ideal for growers. Of course, in order to assess the usefulness of these technologies, they should be assessed in realistic field settings where the virus and vector are present to more accurately mirror situations encountered by growers.

Preventative measures such as good sanitary practices and the use of virus-tested propagation material derived from certified stocks remain the most effective tools against viral diseases. Once viruses and their vectors become established in vineyard settings, their elimination can be cumbersome or nearly impossible. As demonstrated in this review, establishing a new vineyard with virus-resistant materials is not an option with currently available rootstocks and cultivars. Research is ongoing in many locations to develop new grapevine materials that will provide useful resistance against viruses.

\section{Literature Cited}

Aballay, E., D.F. Benavides, and A. Vieira. 1998. Resistance of some grapevine rootstocks to a Chilean population of Xiphinema index. Nematol. Medit. 26:185-188.

Abracheva, P. 1981. Susceptibility of some grapevine varieties to rugose wood (legno riccio). Phytopath. Medit. 20:203-205.

Allen, W.R., H.F. Dias, J.G. van Schagen. 1982. Susceptibility of grape cultivars and rootstocks to an Ontario isolate of tomato ringspot virus. Canadian J. Plant Pathol. 4:275-277.

Andret-Link, P., C. Laporte, L. Valat, C. Ritzenthaler, G. Demangeat, E. Vigne, V. Laval, P. Pfeiffer, C. Stussi-Garaud, and M. Fuchs. 2004. Grapevine fanleaf virus: Still a major threat to the grapevine industry. J. Plant Pathol. 86:183-195. 
Anwar, S.A., and M.V. McKenry. 2000. Penetration, development, and reproduction of Meloidogyne arenaria on two new resistant Vitis spp. Nematropica 30:9-17.

Anwar, S.A., and M.V. McKenry. 2002. Developmental response of a resistance-breaking population of Meloidogyne arenaria on Vitis spp. J. Nematol. 34:28-33.

Becker, H. 1989. The new rootstock Börner (in German). Deutsche Weinbau 44:960-962.

Becker, H., and E. Sopp. 1990. Rootstocks with immunity to phylloxera and nematode resistance. In Proceedings of the 5th International Symposium on Grape Breeding. St. Martin/Pfalz, Germany, 12-16 Sept 1989. Vitis (special issue):294.

Boscia, D., V. Savino, V. Elicio, S.D. Jebahi, and G.P. Martelli. 1991. Detection of closteroviruses in grapevine tissues. In Proceedings of the 10th Meeting of the International Council for the Study of Viruses and Virus Diseases of the Grapevine. Volos, Greece, 3-7 Sept 1990. I.C. Rumbos et al. (eds.), pp. 52-57. ORES Publishing, Volos.

Boubals, D., and R. Pistre. 1978. Resistance of some Vitaceae and usual rootstocks to Xiphinema index and contamination by fanleaf virus. In Grapevine Genetics and Breeding: 2nd International Symposium on Grapevine Breeding. Bordeaux, France, 14-18 June 1977. R. Pouget and J.P. Doazan (eds.), pp. 199-208. Institut National de la Recherche Agronomique, Paris.

Bouquet, A. 1981. Resistance to grapevine fanleaf virus in muscadine grape inoculated with Xiphinema index. Plant Dis. 65:791-793.

Bouquet, A. 1983a. Research on resistant rootstocks: A new way of controlling grapevine fanleaf virus. Prog. Agric. Vitic. 100:256-259.

Bouquet, A. 1983b. Resistance of muscadine grape to transmission of grape fanleaf virus by the nematode Xiphinema index. Agronomie 3:94-95.

Bouquet, A., and Y. Danglot. 1983. Search for grape rootstocks resistant to the transmission of grape fanleaf virus (GFV) by the nematode Xiphinema index. Thorne and Allen. 1. Enzyme-linked immunosorbent-assay as a quick method of selection. Agronomie 3:957-963.

Bouquet, A., Y. Danglot, L. Torregrosa, M. Bongiovanni, and P. Castagnone-Sereno. 2000. Breeding rootstocks resistant to grape fanleaf virus spread using Vitis x Muscadinia hybridization. Acta Hortic. 528:517-526.

Bouquet, A., L. Torregrosa, and P. Chatelet. 2003a. Combined use of conventional and biotechnological methods in the selection of rootstocks with double resistance to the transmission of grape fanleaf virus, $1^{\text {st }}$ part (in French). Prog. Agric. Vitic. 120:507-512.

Bouquet, A., L. Torregrosa, and P. Chatelet. 2003b. Combined use of conventional and biotechnological methods in the selection of rootstocks with double resistance to the transmission of grape fanleaf virus, $2^{\text {nd }}$ part (in French). Prog. Agric. Vitic. 120:528-532.

Buddenhagen, I.W. 1981. Conceptual and practical considerations when breeding for tolerance or resistance. In Plant Disease Control: Resistance and Susceptibility. R.C. Staples and G.H. Torenniessen (eds.), pp. 221-234. Wiley \& Sons, New York.

Burger, P., A. Bouquet, and M.J. Striem. 2009. Grape breeding. In Breeding Plantation Tree Crops: Tropical Species. S.M. Jain and P.M. Priyadarshan (eds.), pp. 161-189. Springer Science, New York.

Credi, R., and A. Santucci. 1991. Serological detection of grapevine leafroll-associated closterovirus-like particles: Apparent absence of viral antigens in leaves of graft-inoculated American rootstocks. In Proceedings of the 10th Meeting of the International Council for the Study of Viruses and Virus Diseases of the Grapevine. Volos, Greece, 3-7 Sept 1990. I.C. Rumbos et al. (eds.), pp. 71-80. ORES Publishing, Volos.

Credi, R., O. Silvestroni, A. Santucci, and A. Canova. 1991. Variation in grapevine rootstock susceptibility to the rugose wood disease "legno riccio." Phytopath. Medit. 30:41-46.
Coiro, M.I., F. Lamberti, M. Borgo, and E. Egger. 1985. Reproduction of Xiphinema index on different grapevine rootstocks. Phytopath. Medit. 24:177-179.

Coiro, M.I., C.E. Tayler, M. Borgo, and F. Lamberti. 1990. Resistance of grapevine rootstocks to Xiphinema index. Nematol. Medit. 18:119-121.

Dias, H.F. 1980. The Grapevine Joannes-Seyve virus: Cultivar susceptibility and transmission studies. In Proceedings of the 7 th Meeting of the International Council for the Study of Viruses and Virus-like Diseases of the Grapevine. Niagara Falls, Canada, 8-12 Sept 1980. A.J. McGinnis (ed.), pp. 113-117. Agriculture Canada, Vineland Station, Ontario.

Esmenjaud, D., and A. Bouquet. 2009. Selection and application of resistant germplasm for grapevine nematodes management. In Integrated Management of Fruit Crops and Forest Nematodes. Vol. 4. A. Ciancio and K.G. Mukerj (eds.), pp. 195-214. Springer Science, New York.

Esmenjaud, D., C. Van Ghelder, R. Voisin, L. Bordenave, S. Decroocq, A. Bouquet, and N. Ollat. 2010. Host suitability of Vitis and VitisMuscadina material to the nematode Xiphinema index over one to four years. Am. J. Enol. Vitic. 61:96-101.

Fraile, A., and F. García-Arenal. 2010. The coevolution of plants and viruses: Resistance and pathogenicity. Adv. Virus Res. 76:1-32.

Fuchs, M. 2003. Transgenic resistance: State of the art and perspectives. In 14th Meeting of the International Council for the Study of Virus and Virus-like Diseases of the Grapevine: Extended Abstracts. Locorotondo, Italy, 12-17 Sept 2003. Dept. of Plant Protection and Applied Microbiology, University of Bari, Italy.

Gonsalves, D. 1982. Reaction of grape varieties to tomato ring spot virus. Dev. Ind. Microbiol. 23:91-97.

Hafner, P. 1998. Börner: A new grape rootstock. Obstbau Weinbau 35:370.

Harris, A.R. 1983. Resistance of some Vitis rootstocks to Xiphinema index. J. Nematol. 15:405-409.

Harris, A.R. 1988. Xiphinema index-resistant Vitis rootstocks screened for comparative field performance in a Chasselas vineyard replant site. Vitis 27:243-251.

Harrison, B.D., and T.M.A. Wilson. 1999. Milestones in research on Tobacco mosaic virus. Phil. Trans. R. Soc. Lond. B 354:521-529.

Haviv, S., N. Galiakparov, D.E. Goszczynski, O. Batuman, H. Czosnek, and M. Mawassi. 2006. Engineering the genome of Grapevine virus $A$ into a vector for expression of proteins in herbaceous plants. $\mathrm{J}$. Virol. Meth. 132:227-231.

Hewitt, W.B., D.J. Raski, and A.C. Goheen. 1958. Nematode vector of soil-borne fanleaf virus of grapevines. Phytopathology 48:586-595.

Hull, R. 2002. Control and uses of plant viruses. In Matthew's Plant Virology. 4th ed., pp. 675-741. Academic Press, New York.

Hwang, C.F., K. Xu, R. Hu, R. Zhou, S. Riaz, and M.A. Walker. 2010. Cloning and characterization of XiRl, a locus responsible for dagger nematode resistance in grape. Theor. Appl. Genet. 121:789-799.

Ioannou, N., A. Hadjnicolis, A. Hadjinicoli. 1997. Epidemiology of the grapevine leafroll-mealybug complex in Cyprus. In Extended Abstracts: 12th Meeting of the International Council for the Study of Virus of Virus and Virus-like Diseases of the Grapevine. Lisbon, Portugal, 28 Sept-2 Oct 1997. O.A. Sequeira et al. (eds.), pp. 123 124. Estação Agraonomica Nacional, Oeiras, Portugal.

Ipach, U., L. Kling, and M. Rüdel. 2000. Transmission of grapevine fanleaf virus by Xiphinema index to different newly bred rootstocks in greenhouse and field trials. In Extended Abstracts: 13th Meeting of the International Council for the Study of Virus of Virus and Viruslike Diseases of the Grapevine. Adelaide, Australia, 12-17 March 2000. R.H. Symons (ed.), p. 66. University of Adelaide, Australia.

Jaillon, O., et al. 2007. The grapevine genome sequence suggests ancestral hexaploidization in major angiosperm phyla. Nature 449:463-467. 
Jia, L., and M.A. Walker. 1995. Evaluation of embryo-rescued seedlings of Thompson Seedless for resistance to Grapevine fanleaf virus. Abstr. Am. J. Enol. Vitic. 46:415.

Jimenez Diaz, F., and A.C. Goheen. 1991. Resistance to fanleaf virus among grape cultivars and Vitis species. Revista Mex. Fitopatol. 9:47-49.

Kovacs, L.G., H. Hanami, M. Fortenberry, and M.L. Kaps. 2001. Latent infection by leafroll agent GLRaV-3 is linked to lower fruit quality in French-American hybrid grapevines Vidal blanc and St. Vincent. Am. J. Enol. Vitic. 52:254-259.

Kunde, R.M., L.A. Lider, and R.V. Schmitt. 1968. A test of Vitis resistance to Xiphinema index. Am. J. Enol. Vitic. 19:30-36.

Lahogue, F., and G. Boulard. 1996. Recherche de gènes de résistance naturelle à deux viroses de la vigne: Le court-noué et l'enroulement. Vitis 35:43-48.

Lahogue, F., G. Boulard, and C. Schneider. 1995. Comparaison de diferentes techniques de greffage vis-à-vis de leur efficacite de transmission virale sur vigne. Vitis 34:177-183.

Laimer, M., O. Lemaire, E. Herrbach, V. Goldschmidt, A. Minafra, P. Bianco, and T. Wetzel. 2009. Resistance to viruses, phytoplasmas and their vectors in the grapevine in Europe: A review. J. Plant Pathol. 91:7-23.

Lapidot, M., R. Ben-Joseph, L. Cohen, Z. Machbash, and D. Levy. 2006. Development of a scale for evaluation of Tomato yellow leaf curl virus resistance level in tomato plants. Phytopathology 96:1404-1408.

Lecoq, H., B. Moury, C. Desbiez, A. Palloix, and M. Pitrat. 2004. Durable virus resistance in plants through conventional approaches: A challenge. Virus Res. 100:31-39.

Lider, L.A., and A.C. Goheen. 1986. Field resistance to the grapevine fanleaf virus - Xiphinema index complex in interspecific hybrids of Vitis. In 4th International Symposium on Grapevine Breeding. Verona, Italy, 13-18 Apr 1985. VigneVini 13 (Suppl. 12):166-169.

Malan, A.P., and A.J. Meyer. 1993. Interaction between a South African population of Xiphinema index and different grapevine rootstocks. S. Afr. J. Enol. Vitic. 14:11-15.

Martelli, G.P., and E. Boudon-Padieu. 2006. Directory of infectious diseases of grapevines and viruses and virus-like diseases of the grapevine: Bibliographic report 1998-2004, pp. 9-194. Opt. Méditer. Série B, n. 55. CIHEAM-IAMB, Bari, Italy.

Maule, A.J., C. Caranta, and M.I. Boulton. 2007. Sources of natural resistance to plant viruses: Status and prospects. Mol. Plant Pathol. $8: 223-231$.

McKenry, M.V., and S.A. Anwar. 2006. Nematode and grape rootstock interactions including an improved understanding of tolerance. J. Nematol. 38:312-318.

McKenry, M.V., J.O. Kretsch, and S.A. Anwar. 2001. Interactions of selected rootstocks with ectoparasitic nematodes. Am. J. Enol. Vitic. 52:304-309.

McKenry, M.V., D. Luvisi, S.A. Anwar, P. Schrader, and S. Kaku. 2004. Eight-year nematode study from uniformly designed rootstock trials in fifteen table grape vineyards. Am. J. Enol. Vitic. 55:218-227.

Meredith, C.P., L.A. Lider, D.J. Raski, and N.L. Ferrari. 1982. Inheritance of tolerance to Xiphinema index in Vitis species. Am. J. Enol. Vitic. 33:154-158.

MFK Research. 2007. Impact of Wine, Grapes, and Grape Products on the American Economy 2007: Family Businesses Building Value. MFK Research, Wine Business Center, St. Helena, CA.

Muruganantham, M., Y. Moskovitz, S. Haviv, T. Horesh, A. Fenigstein, J. du Preez, D. Stephen, J.T. Burger, and M. Mawassi. 2009. Grapevine virus $A$-mediated gene silencing in Nicotiana benthamiana and Vitis vinifera. J. Virol. Meth. 155:167-174.
Oliver, J.E., P.F. Tennant, and M. Fuchs. 2011. Virus-resistant transgenic horticultural crops: Safety issues and risk assessment. In Transgenic Horticultural Crops: Challenges and Opportunities. B. Mou and R. Scorza (eds.), pp. 263-287. CRC Press, Boca Raton, FL.

Peng, Y., and M. Moens. 2003. Host resistance and tolerance to migratory plant-parasitic nematodes. Nematology 5:145-177.

Ramsdell, D.C., J.M. Gillett, and G.W. Bird. 1995. Susceptibility of American grapevine scion cultivars and French hybrid rootstock and scion cultivars to infection by peach rosette mosaic nepovirus. Plant Dis. 79:154-157.

Ramsdell, D.C., G.W. Bird, F.W. Warner, J.F. Davenport, C.J. Diamond, and J.M. Gillett. 1996. Field pathogenicity studies of four species of plant-pathogenic nematodes on French-American hybrid grapevine cultivars in Michigan. Plant Dis. 80:334-338.

Raski, D.J., A.C. Goheen, L.A. Lider, and C.P. Meredith. 1983. Strategies against Grapevine fanleaf virus and its nematode vector. Plant Dis. 67:335-339.

Sabanadzovic, S. 2009. Viruses of native Vitis germplasm in the southeastern United States. In Extended Abstracts: 16th Meeting of the International Council for the Study of Virus and Virus-like Diseases of the Grapevine, 31 Aug-4 Sept 2009, Dijon, France. E. BoudonPadieu (ed.), pp. 32-35. Progrès Agricole et Viticole, Monptellier.

Smith, B., K. Skogerson, and A. Walker. 2005. Correlating root system cytokinin production with tolerance to fanleaf. Abstr. Am. J. Enol. Vitic. 56:299A-300A

Sopp, E., E.H. Rühl, and H. Holst. 1998. Resistance of rootstocks to the virus transmitting nematode Xiphinema index. Viticult. Enol. Sci. 53:3-6.

Staudt, G. 1997. A quick-test for screening resistance to transmission of grapevine fanleaf virus by Xiphinema index. Vitis 36:155-156.

Staudt, G., and H.H. Kassemeyer. 1990. Resistance to transmission of grapevine fanleaf virus by Xiphinema index in some Vitis species and hybrids. In Proceedings of the 5th International Symposium on Grape Breeding. St. Martin/Pfalz, Germany, 12-16 Sept 1989. Vitis (special issue):223-227.

Staudt, G., and B. Weischer. 1992. Resistance to transmission of grapevine fanleaf virus by Xiphinema index in Vitis rotundifolia and Vitis munsoniana. Vitic. Enol. Sci. 47:56-61.

Stellmach, G., and R.E. Berres. 1986. Limited susceptibility of Vitis vinifera cv. Kerner for infections with Arabis mosaic virus. Z. Pflanzenkrankheiten Pflanzenschutz 93:356-360.

Stobbs, L.W., and A.B. Broadbent. 1993. Susceptibility of grapevine cultivars to Tomato spotted wilt virus in southern Ontario, Canada. Plant Dis. 77:318.

Stobbs, L.W., J.W. Potter, R. Killins, and J.G. Van Schagen. 1988. Influence of grapevine understock in infection of DeChaunac scion by tomato ringspot virus. Can. J. Plant Pathol. 10:228-231.

Téliz, D., and P. Valle. 1980. Grape corky bark and stem pitting in Mexico: III. Evaluation of symptoms in 130 cultivars grafted on 17 rootstocks. In Proceedings of the 7th Meeting of the International Council for the Study of Viruses and Virus-like Diseases of the Grapevine. Niagara Falls, Canada, 8-12 Sept 1980. A.J. McGinnis (ed.), pp. 71-75. Agriculture Canada, Vineland Station, Ontario.

Téliz, D., P. Valle, A.C. Goheen, and S. Luévano. 1980a. Grape corky bark and stem pitting in Mexico: I. Occurrence, natural spread, distribution, effect on yield and evaluation of symptoms in 128 grape cultivars. In Proceedings of the 7th Meeting of the International Council for the Study of Viruses and Virus-like Diseases of the Grapevine. Niagara Falls, Canada, 8-12 Sept 1980. A.J. McGinnis (ed.), pp. 51-64. Agriculture Canada, Vineland Station, Ontario.

Téliz, D., P. Valle, and A.C. Goheen. 1980b. Grape corky bark and stem pitting in Mexico: II. Evaluation of symptoms in 17 rootstocks In Proceedings of the 7th Meeting of the International Council for 
the Study of Viruses and Virus-like Diseases of the Grapevine. Niagara Falls, Canada, 8-12 Sept 1980. A.J. McGinnis (ed.), pp. 65-70. Agriculture Canada, Vineland Station, Ontario.

Téliz, D., P. Valle, and A.C. Goheen. 1981. Evaluation of corky bark and stem pitting symptoms in 18 grape rootstocks in Aguascalientes, Mexico. Phytopathology 71:109.

Trudgill, D.L. 1991. Resistance to and tolerance of plant parasitic nematodes in plants. Ann. Rev. Phytopathol. 29:167-192.

Uyemoto, J.K., J.R. Cummins, and G.S. Abawi. 1977. Virus and viruslike diseases affecting grapevines in New York vineyards. Am. J. Enol. Vitic. 28:131-136.

Valat, L., M. Burrus, M. Fuchs, and M.C. Mauro. 2003. Review of techniques to inoculate grapevines with Grapevine fanleaf virus: Lessons and perspectives. Am. J. Enol. Vitic. 54:279-285.

Van Zyl, S., M.A. Vivier, and M.A. Walker. 2009. Inheritance of $\mathrm{Xi}$ phinema index resistance derived from Vitis arizonica. Abstr. Am. J. Enol. Vitic. 60:408A.

Velasco, R., et al. 2007. A high quality draft consensus sequence of the genome of a heterozygous grapevine variety. PLoS One 2:1-18.

Vigne, E., V. Komar, and M. Fuchs. 2004. Field safety assessment of recombination in transgenic grapevines expressing the coat protein of Grapevine fanleaf virus. Trans. Res. 13:165-179.

Walker, A. 2009. Nematode-resistant rootstocks released to nurseries. Pract. Winery Vineyard Jan/Feb:1-3.

Walker, M.A., and Y.M. Jin. 1998. Development of resistant rootstocks to control Xiphinema index and fanleaf degeneration. Acta Hortic. 473:113-120.

Walker, M.A., and Y.M. Jin. 2000. Breeding Vitis rupestris x Muscadinia rotundifolia rootstocks to control Xiphinema index and fanleaf degeneration. Acta Hortic. 528:511-515.

Walker, M.A., and C.P. Meredith. 1990. The genetics of resistance to Grapevine fanleaf virus in Vitis vinifera. In Proceedings of the 5th International Symposium on Grape Breeding. St. Martin/Pfalz, Germany, 12-16 Sept 1989. Vitis (special issue):228-238.
Walker, M.A., and J.A. Wolpert. 1994. Field screening of grape rootstock selections for resistance to fanleaf degeneration. Plant Dis. 78:134-136.

Walker, M.A., L.A. Lider, A.C. Goheen, and H.P. Olmo. 1991. VR 039-16 grape rootstock. HortScience 26:1224-1225.

Walker, M.A., C.P. Meredith, and A.C. Goheen. 1985. Sources of resistance to grapevine fanleaf virus (GFV) in Vitis species. Vitis 24:218-228.

Walker, M.A., J.A. Wolpert, E.P. Vilas, A.C. Goheen, and L.A. Lider. 1989. Resistant rootstocks may control fanleaf degeneration of grapevines. Calif. Agric. 2:13-14.

Walker, M.A., J.A. Wolpert, and E. Weber. 1994. Viticultural characteristics of VR hybrid rootstocks in a vineyard site infected with Grapevine fanleaf virus. Vitis 33:19-23.

Weischer, B. 1980. The host-parasite relationships between the vector nematode, Xiphinema index, and some Vitis spp. In Proceedings of the 7th Meeting of the International Council for the Study of Viruses and Virus-like Diseases of the Grapevine. Niagara Falls, Canada, 8-12 Sept 1980. A.J. McGinnis (ed.), pp. 139-146. Agriculture Canada, Vineland Station, Ontario.

Wheeler, J., and A. Walker. 2005. Resistance to Xiphinema index in a population of Vitis species collected in northern Mexico. Abstr. Am. J. Enol. Vitic. 56:299A.

Wolpert, J.A., and E.P. Vilas. 1992. Effect of mild leafroll disease on growth, yield, and fruit maturity indices of Riesling and Zinfandel. Am. J. Enol. Vitic. 43:367-369.

Xu, K., S. Riaz, N.C. Roncoroni, Y. Jin, R. Hu, R. Zhou, and M.A. Walker. 2008. Genetic and QTL analysis of resistance to Xiphinema index in a grapevine cross. Theor. Appl. Genet. 116:305-311.

Zhang, Y., K. Singh, R. Kaur, and W. Qiu. 2011. Association of a novel DNA virus with the grapevine vein-clearing and vine decline syndrome. Phytopathology 101:1081-1090. 